\title{
FACTORS THAT AFFECT FINANCIAL DISTRESS IN INDONESIA
}

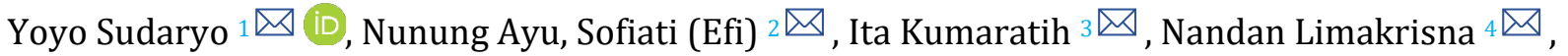 \\ Mohd Hassan Che Haat ${ }^{5} \bowtie$, Zikri Muhammad ${ }^{6} \bowtie$, Astrin Kusumawardani ${ }^{7} \bowtie$, Jumadil Saputra ${ }^{8} \bowtie$ \\ 1, 2, 3, 7 Indonesia Membangun University, Bandung, Indonesia. \\ ${ }^{4}$ Persada Indonesia University Y.A.I, Jakarta, Indonesia. \\ 5, 6, 8 Faculty of Business, Economics and Social Development Universiti Malaysia Terengganu.
}

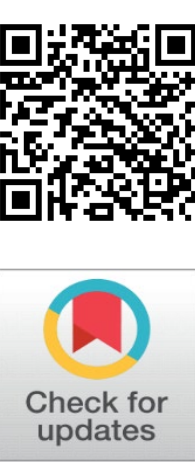

\section{ABSTRACT}

The results show that, it is proven that the variable liquidity and interest rates have a negative effect on financial distress. Meanwhile, the variables of Profitability, Leverage and Company Size have a positive effect on financial distress. While the Economic Stimulus variable is known to be the relationship between all variables of Liquidity, Profitability, Leverage, Company Size and Interest Rate on variables to Financial Distress. This means that company leaders must take into account liquidity, profitability, leverage, company size and interest rates to avoid financial distress.

Received 1 September 2021

Accepted 15 September 2021

Published 30 September2021

\section{CorrespondingAuthor}

Yoyo Susdaryo,

y.sudaryo2@gmail.com

DOI

10.29121/granthaalayah.v9.i9.2021. 4269

Funding: This research received no specific grant from any funding agency in the public, commercial, or not-for-profit sectors.

Copyright: (C) 2021 The Author(s). This is an open access article distributed under the terms of the Creative Commons Attribution License, which permits unrestricted use, distribution, and reproduction in any medium, provided the original author and source are credited.
Keywords: Liquidity, Profitability, Leverage, Company Size, Interest Rates, Financial Distress

\section{INTRODUCTION}

A company can be categorized as experiencing financial distress if the company has a performance that shows negative net income. When firm experiences corporate financial distress, the operating conditions of the firm deteriorate thus leading to heavy financial burden on the firm resulting to inability of the firm in paying both secured, preferential and unsecured creditors (Garlappi and Yan, 2011; Benmelech et al., 2012) in Fredrick (2019).

Liquidity ratios show the entity's ability to meet its short-term liabilities, as the weakness of the value of these ratios indicates that the organization may face difficulties in meeting short-term financial liabilities (Amengor, 2010) in Durrah (2016).

Type of Financial Ratios Profitability Ratios Brigham and Houston (2010: 149) in Dai (2016) argues that the ratio of profitability is a group that shows the ratio of the combination of the effects of liquidity, asset management, and debt on operating results, From the above definition it is known that a ratio that provides information on a company's ability to benefit by utilizing the resources available within the company.

Leverage ratio is a ratio that measures the ratio of funds provided by the owner of funds borrowed from creditor companies. This ratio shows the company's ability to meet its financial obligations, both short and long term (Abdul:2013) in Makiwan (2018). In this study, leverage is measured by a debt asset ratio (DAR). Debt asset ratio (DAR) is the ratio of debt to total assets which can be called a debt ratio, which measures the percentage of funds originating from debt. What is meant by debt is all debts owned by the company, both short- 
term debt and long-term debt. Creditors prefer a lower debt ratio because the security level of funds is getting better Sutrisno (2012).

Firm Size is scale to determine the size of a company which can be proxied in several ways, including total assets and total sales (Total Sales) (Saemargani, 2015) in Wufron (2017). The size of the company can also show how much information it contains, as well as reflect the awareness of management about the importance of information, both for external parties and for internal parties. The bigger the company size, the more information it contains.

The interest rate is the cost of borrowing, and is usually a percentage of the amount borrowed. In Indonesia, the interest rate is determined by Bank Indonesia as the central bank. The interest rate strategy implemented by BI to stabilize the rupiah exchange rate cannot be carried out continuously, considering that banks need to carry out the banking intermediary function more freely with low interest rates.

\begin{tabular}{|c|c|c|c|c|}
\hline \multicolumn{5}{|c|}{ Table 1 Net Profit } \\
\hline \multirow[t]{2}{*}{ Indeks } & \multicolumn{4}{|c|}{ Net Profit } \\
\hline & 2014 & 2015 & 2016 & 2017 \\
\hline ADMG & 2.819 & 34.437 & 10.863 & (611) \\
\hline ARGO & (244.579) & (241.058) & $(138.823)$ & 415.265 \\
\hline BATA & 4.601 & 4.272 & 5.233 & 3.348 \\
\hline ESTI & 111 & 582 & $(4.667)$ & (6.671) \\
\hline HDTX & 4.287 & 1.293 & 232 & $(16.354)$ \\
\hline IMAS & 33.582 & 80.927 & 66.193 & 60.083 \\
\hline INDR & 26.000 & 8.000 & 1.000 & 1.600 \\
\hline INTA & 6.213 & 8.991 & 929 & (18.596) \\
\hline LPIN & 1.056 & 846 & 1.241 & 639 \\
\hline MASA & 13.158 & 6.943 & 320 & 3.601 \\
\hline PRAS & 2 & 529 & 3.091 & 6.500 \\
\hline SRSN & 732 & 1.787 & 1.263 & 1.192 \\
\hline \multirow[t]{2}{*}{ Indeks } & \multicolumn{3}{|c|}{ Net Profit } & \\
\hline & 2018 & 2019 & 2020 & \\
\hline ADMG & $(25.491)$ & $(22.886)$ & $(22.309)$ & \\
\hline ARGO & $(30.333)$ & (11.021) & $(25.344)$ & \\
\hline BATA & 5.264 & 9.727 & 3.172 & \\
\hline ESTI & (6.389) & $(10.485)$ & 3.127 & \\
\hline HDTX & $(7.746)$ & $(26.601)$ & $(29.436)$ & \\
\hline IMAS & 597 & (671) & $(746)$ & \\
\hline INDR & (200) & 10.100 & 1.500 & \\
\hline INTA & $(5.762)$ & $(23.126)$ & $(14.445)$ & \\
\hline LPIN & (704) & (1.359) & $(4.789)$ & \\
\hline MASA & (311) & $(27.120)$ & (6.483) & \\
\hline PRAS & 8.297 & 3.698 & $(2.286)$ & \\
\hline SRSN & 1.088 & 1.155 & 823 & \\
\hline
\end{tabular}

The decline in operating profit occurred in several manufacturing companies, 12 of the 30 companies experienced a decrease in operating profit. There are 8 manufacturing companies including PT Polychem Indonesia (ADMG), PT Indo Acidatama Tbk (ARGO), PT Panasia Indosyntec Tbk (HDTX), PT Indo Mobil Sukses Internasional Tbk (IMAS), PT Intraco Penta Tbk (INTA), PT Multi Prima Sejahtera Tbk (LPIN), PT Multstrada Prima Sarana Tbk (MASA), and PT Prima Alloy Steel Tbk (PRAS). A company that is categorized as experiencing financial distress is if the company experiences negative operating profit for two consecutive years.

Menurut hasil penelitian Sudaryo et al. (2021), Hasan (2008) hasil penelitian ini menemukan bahwa likuiditas, profitabilitas, leverage, dan suku bunga 
berpengaruh signifikan terhadap Financial Distress. Sedangkan menurut Sudaryo et al. (2021), The results showed that (1) Financial Distress calculated by the Altman Zscore formula averaged 1,895, which means that the company is in a vulnerablecondition and is experiencing financial problems and must immediately handle propermanagement management. (2) Current Ratio (CR) an average of $117.63 \%<200 \%$, thisercentage indicates that they have a low enough ability to pay their short-termobligations. (3) Debt to Equity Ratio (DER) an average of $116.59 \%>$ $80 \%$ indicates alow company's ability to pay its long-term debt. (4) Net Profit Margin (NPM) anaverage of $15.37 \%<20 \%$ indicates that the company cannot generate higher profits. (5) Current Ratio (CR) has a significant effect on Financial Distress. (6) Debt to Equity Ratio (DER) has a significant effect on Financial Distress. (7) Net Profit Margin (NPM)has no significant effect on Financial Distress. (8) Current Ratio (CR), Debt to Equity Ratio (DER) and Net Profit Margin (NPM) have a significant effect on FinancialDistress.

\section{METHOD}

The method used in this research is a quantitative method with a descriptive and verification method approach. Quantitative research methods according to Sugiyono (2014) The method used in this research is a quantitative method with a descriptive and verification method approach. Quantitative research methods according to Sugiyono (2014) What is meant by descriptive analysis method is as follows: "Descriptive analysis method is a statistic used to analyze data by describing or describing the collected data as it is looking for a relationship between two or more variables." The verification method according to Hasan (2008) is "a research method that aims to test the truth of something in a previously existing field".

\begin{tabular}{|c|c|c|c|}
\hline \multicolumn{4}{|c|}{ Tabel 2 Journal and Publisher Distribution } \\
\hline No & Article Name & Author(s) & Journal Publisher \\
\hline 1 & $\begin{array}{l}\text { Predicting Nursing Home Financial Distress } \\
\text { Using the Altman Z-Score }\end{array}$ & $\begin{array}{l}\text { Lord et al. } \\
\quad(2020)\end{array}$ & $\begin{array}{l}\text { INQUIRY: The Journal of } \\
\text { Health Care } \\
\text { Organization, Provision, } \\
\text { and Financing }\end{array}$ \\
\hline 2 & $\begin{array}{l}\text { Financial distress prediction using support } \\
\text { vector machines: Ensemble vs. individual }\end{array}$ & $\begin{array}{l}\text { Souri et al. } \\
\text { (2018) }\end{array}$ & Elsevier \\
\hline 4 & $\begin{array}{l}\text { Bank power, block ownership, boards and } \\
\text { financial distress likelihood: An } \\
\text { investigation of Spanish listed firms }\end{array}$ & $\begin{array}{l}\text { Mangena and } \\
\text { Manzaneque. } \\
\quad(2020)\end{array}$ & Elsevier \\
\hline 5 & $\begin{array}{l}\text { Combining corporate governance indicators } \\
\text { with stacking ensembles for financial } \\
\text { distress prediction }\end{array}$ & $\begin{array}{l}\text { Liang et al. } \\
\text { (2020) }\end{array}$ & Elsevier \\
\hline 6 & $\begin{array}{l}\text { Going concern modifications and related } \\
\text { disclosures in the Italian stock market: do } \\
\text { regulatory improvements help investors in } \\
\text { capturing financial distress? }\end{array}$ & $\begin{array}{l}\text { Brunelli et al. } \\
\qquad(2020)\end{array}$ & $\begin{array}{l}\text { Journal of Management } \\
\text { and Governance }\end{array}$ \\
\hline 7 & $\begin{array}{l}\text { The Effect of Financial Distress and Growth } \\
\text { Opportunities on Accounting Conservatism } \\
\text { with Litigation Risk as Moderated Variables } \\
\text { in Manufacturing Companies Listed on BEI }\end{array}$ & Sari (2020) & $\begin{array}{l}\text { Budapest International } \\
\text { Research and Critics } \\
\text { Institute-Journal (BIRCI- } \\
\text { Journal) }\end{array}$ \\
\hline 8 & $\begin{array}{c}\text { Earnings Management and Financial } \\
\text { Distress: An Analysis of Indian Textile } \\
\text { Companies }\end{array}$ & $\begin{array}{l}\text { Paul and Rakshit } \\
\text { (2020) }\end{array}$ & $\begin{array}{l}\text { NMIMS Journal Of } \\
\text { Economics And Public } \\
\text { Policy }\end{array}$ \\
\hline
\end{tabular}


Yoyo Sudaryo, Nunung Ayu, Sofiati (Efi), Ita Kumaratih, Nandan Limakrisna, Mohd Hassan Che Haat, Zikri Muhammad, Astrin Kusumawardani, and Jumadil Saputra

\begin{tabular}{|c|c|c|c|}
\hline 9 & $\begin{array}{c}\text { Financial Distress: The Impacts Of } \\
\text { Profitability, Liquidity, Leverage, Firm Size, } \\
\text { And Free Cash Flow }\end{array}$ & Dirman (2020) & $\begin{array}{l}\text { International Journal of } \\
\text { Business, Economics and } \\
\text { Law }\end{array}$ \\
\hline 10 & $\begin{array}{c}\text { The Impact of CSR and Financial Distress on } \\
\text { Financial Performance-Evidence from } \\
\text { Chinese Listed Companies of the } \\
\text { Manufacturing Industry }\end{array}$ & Wu et al. (2020) & Sustainability \\
\hline 11 & $\begin{array}{c}\text { Predicting Financial Distress of Slovak } \\
\text { Enterprises: Comparison of Selected } \\
\text { Traditional and Learning Algorithms } \\
\text { Methods }\end{array}$ & $\begin{array}{l}\text { Gregova et al. } \\
\qquad(2020)\end{array}$ & Sustainability \\
\hline 12 & $\begin{array}{c}\text { Financial Distress Prediction and Feature } \\
\text { Selection in Multiple Periods by Lassoing } \\
\text { Unconstrained Distributed Lag Non-linear } \\
\text { Models }\end{array}$ & Yan et al. (2020) & Mathematics \\
\hline 13 & $\begin{array}{c}\text { Return Premium of Financial Distress and } \\
\text { Negative Book Value: Emerging } \\
\text { Market Case }\end{array}$ & $\begin{array}{l}\text { Kakinuma, } \\
\text { (2020) }\end{array}$ & $\begin{array}{l}\text { Journal of Asian Finance } \\
\text { Economics and Business }\end{array}$ \\
\hline 14 & $\begin{array}{l}\text { Effect of financial distress on firm's } \\
\text { performance of non-financial firms } \\
\text { registered with Pakistan Stoke Exchange. }\end{array}$ & $\begin{array}{l}\text { Ahmad et al. } \\
\qquad(2020)\end{array}$ & $\begin{array}{l}\text { International Journal of } \\
\text { Business and } \\
\text { Management Sciences }\end{array}$ \\
\hline 15 & $\begin{array}{l}\text { Firm specific determinants of financial } \\
\text { distress: Empirical evidence from Nigeria }\end{array}$ & Fredrick (2019) & $\begin{array}{l}\text { Journal of Accounting } \\
\text { and Taxation }\end{array}$ \\
\hline 16 & $\begin{array}{l}\text { How Indonesia Economics Works: } \\
\text { Correlation Analysis of Macroeconomics in } \\
2010-2019\end{array}$ & $\begin{array}{l}\text { Olilingo et al. } \\
\qquad(2020)\end{array}$ & $\begin{array}{l}\text { Journal of Asian Finance, } \\
\text { Economics and Business }\end{array}$ \\
\hline 17 & $\begin{array}{l}\text { The Great Lockdown and The Big Stimulus: } \\
\text { Tracing the Pandemic Possibility Frontier } \\
\text { for The U.S. }\end{array}$ & $\begin{array}{l}\text { Kaplan et al. } \\
\text { (2020) }\end{array}$ & $\begin{array}{l}\text { NBER Working Paper } \\
\text { Series }\end{array}$ \\
\hline 18 & $\begin{array}{l}\text { How did U.S. Consumers use their stimulus } \\
\text { payments? }\end{array}$ & $\begin{array}{l}\text { Olivier Coibion } \\
\qquad \text { (2019) }\end{array}$ & $\begin{array}{l}\text { NBER Working Paper } \\
\text { Series }\end{array}$ \\
\hline 19 & $\begin{array}{c}\text { Spatial impacts of fiscal stimulus policies } \\
\text { during the } 2009 \text { global financial crisis in } \\
\text { Indonesia }\end{array}$ & $\begin{array}{l}\text { Resosudarmo et } \\
\text { al. (2020) }\end{array}$ & $\begin{array}{l}\text { Asia-Pacific Journal of } \\
\text { Regional Science }\end{array}$ \\
\hline 20 & $\begin{array}{l}\text { Banking credit restructuring policy on the } \\
\text { impact of COVID-19 spread in indonesia }\end{array}$ & $\begin{array}{l}\text { Disemadi and } \\
\text { Shaleh. (2020) }\end{array}$ & Jurnal Inovasi Ekonomi \\
\hline
\end{tabular}

\section{RESULT AND DISCUSSION}

\begin{tabular}{|cccccccc|}
\hline \multicolumn{7}{c}{ Table 3 Results of Multiple Regression Analysis } \\
\hline Model & B & \multicolumn{2}{c}{ Uji t } & Adj R & Uji F \\
\hline (Constant) & .793 & 3.733 & .000 & & & \\
\hline Liqudity & -.517 & -2.253 & .003 & & & \\
\hline Profitability & .152 & 3.619 & .037 & .459 & 4.568 & $.001^{b}$ \\
\hline Leverage & .562 & 3.346 & .001 & & & \\
\hline Size & .230 & 1.861 & .095 & & & \\
\hline Interest Rate & -.197 & -2.735 & .004 & & & \\
\hline
\end{tabular}


Liquidity tends to fluctuate for most of the companies sampled in the study. For the highest liquidity owned by PT. Indo Acidatama Tbk (SRSN), amounting to 328.13. The lowest liquidity of PT. PanasiaIndosyntec Tbk were amounted to 0.99.

The results of descriptive analysis of the Profitability variable showed that the minimum profitability value was $-18.4 \%$ and the maximum profitability value was $16 \%$.

The results of the descriptive analysis of the Leverage variable show that the minimum leverage value is $0.3 \%$ and the maximum leverage value is $93.50 \%$.

The results of the descriptive analysis of the firm size variable show that the minimum value of company size is 6.33 and the maximum value of company size is 20.21.

The results of the descriptive analysis of the Interest Rate variable show that the minimum value of the Interest Rate is $5.75 \%$ and the maximum value of the Interest Rate is $7.75 \%$.

The results of the descriptive analysis of the Financial Distress variable show that the minimum value of Financial Distress is -0.43 and the maximum value of Financial Distress is 1.81 .

Hypothesis 1 in this study states that the liquidity variable has a negative effect on financial distress. Based on the results of regression analysis, the liquidity variable has a negative effect on the financial distress variable. In other words, it can be stated that Hypothesis 1 is accepted.

Hypothesis 2 in this study states that the profitability variable has a positive effect on financial distress. Based on the results of the regression analysis, the Profitability variable shows a positive influence on financial distress. In other words, it can be stated that Hypothesis 2 is accepted.

Hypothesis 3 in this study states that the leverage variable has a positive effect on financial distress. Based on the results of the regression analysis, the leverage variable shows a positive effect on financial distress. In other words, it can be stated that Hypothesis 3 is accepted.

Hypothesis 4 in this study states that the firm size variable has a negative effect on financial distress. Based on the results of the regression analysis, the firm size variable does not show a significant effect on the financial distress variable. In other words, it can be stated that Hypothesis 4 is rejected.

\begin{tabular}{|ccc|}
\hline \multicolumn{3}{|c|}{ Tabel 4 Residual Test Results } \\
\hline Variabel Dependen & t & Sig. \\
\hline Likuiditas & -4.783 & .005 \\
\hline Profitability & -3.795 & .001 \\
Leverage & -3.264 & .000 \\
\hline Size & -2.653 & .005 \\
\hline Interest Rate & -3.523 & .002 \\
\hline
\end{tabular}

Hypothesis 5 in this study states that the interest rate variable has a negative effect on financial distress. Based on the results of regression analysis, the Interest Rate variable shows a negative effect on Financial Distress. In other words, it can be stated that Hypothesis 5 is accepted.

Based on the results of the residual test, it can be seen that the t value for the second regression model is $-4,783$, with a significance level of 0.005 . While the standard beta coefficient value is -0.372 . Because the parameter coefficient value is negative, and the significance value is below 0.05 , it can be concluded that the Economic Stimulus moderating variable is able to moderate the relationship between the Liquidity variable and the Financial Distress variable. This means that 
this is in accordance with the initial hypothesis which states that the moderating variable Economic Stimulus is able to moderate the relationship between the Liquidity variable and the Financial Distress variable. Therefore, it can be concluded that Hypothesis 6a is Proven.

Based on the results of the residual test, it can be seen that the $t$ value for the third regression model is $-3,795$, with a significance level of 0.001 . While the standard beta coefficient value is -0.273 . Because the parameter coefficient value is negative, and the significance value is below 0.05 , it can be concluded that the Economic Stimulus moderating variable is able to moderate the relationship between the Profitability variable and the Financial Distress variable. This means that this is in accordance with the initial hypothesis which states that the moderating variable Economic Stimulus is able to oderate the relationship between the Profitability variable and the Financial Distress variable. Therefore, it can be concluded that Hypothesis $6 \mathrm{~b}$ is Proven.

Based on the results of the residual test, it can be seen that the $t$ value for the fourth regression model is $-3,264$, with a significance level of 0.000 . While the standard beta coefficient value is -0.224 . Because the parameter coefficient value is negative, and the significance value is below 0.05 , it can be concluded that the Economic Stimulus moderation variable is considered to be able to moderate the relationship between the Leverage variable and the Financial Distress variable. This means that this is in accordance with the initial hypothesis which states that the moderating variable Economic Stimulus is able to moderate the relationship between the Leverage variable and the Financial Distress variable. Therefore, it can be concluded that Hypothesis $6 \mathrm{c}$ is Proven.

Based on the results of the residual test, it can be seen that the $t$ value for the fifth regression model is $-2,653$, with a significance level of 0.005 . While the standard beta coefficient value is -0.160 . Because the parameter coefficient value is negative, and the significance value is below 0.05 , it can be concluded that the Economic Stimulus moderating variable is considered to be able to moderate the relationship between the Firm Size variable and the Financial Distress variable. This means that this is in accordance with the initial hypothesis which states that the moderating variable Economic Stimulus is able to moderate the relationship between the Firm Size variable and the Financial Distress variable. Therefore, it can be concluded that Hypothesis $6 \mathrm{~d}$ is Proven.

Based on the results of the residual test, it can be seen that the $t$ value for the sixth regression model is $-3,523$, with a significance level of 0.002 . While the standard beta coefficient value is -0.248 . Because the parameter coefficient value is negative, and the significance value is below 0.05 , it can be concluded that the Economic Stimulus moderation variable is considered to be able to moderate the relationship between the Interest Rate variable and the Financial Distress variable. This means that this is in accordance with the initial hypothesis which states that the moderating variable Economic Stimulus is able to moderate the relationship between the Interest Rate variable and the Financial Distress variable. Therefore, it can be concluded that Hypothesis 6e is Proven.

\section{CONCLUSION}

The results of this study indicate that, from the variables studied, it is proven that the liquidity variable and the interest rate have a negative effect on financial distress. Meanwhile, the variables of Profitability, Leverage and Company Size have a positive effect on financial distress. Meanwhile, the Economic Stimulus variable is 
known to moderate the relationship between all variables of Liquidity, Profitability, Leverage, Company Size and Interest Rate on variables to Financial Distress. This means that company leaders must take into account liquidity, profitability, leverage, company size and interest rates to avoid financial distress. However, it is also necessary to pay attention to the Economic Stimulus which can moderate the relationship of these variables.

\section{RESEARCH IMPLICATION}

The results of this study are expected to contribute policy implications to company management, investors and potential investors as well as other related parties. This implication is considered very important because it can be used as a reference in making decisions related to financial distress that occurs in companies by considering financial ratios such as liquidity, profitability, leverage, company size and interest rates against conditions driven by economic stimuli.

\section{RESEARCH LIMITATION}

In this study, there are several limitations of the study, including the following:

1) The research period used in this study is relatively short, from 2014 to 2020.

2) This research only focuses on the company's internal performance variables in the form of financial ratios which may be expanded by paying more attention to company macro factors or other economic risk factors outside the company's performance.

3) The study involved a limited number of research subjects, so that the results could not be generalized to a large number of subjects.

\section{REFERENCES}

Ahmad, Sardar, Lie Zhang, Adnan Ahmad, and Awais Ahmad. (2020). "Effect of Financial Distress on Firm ' $s$ Performance of Non-Financial Firms Registered with Pakistan Stoke Exchange. School of Management." (May). Retrieved from https://ijbms.org/ojs/index.php/ijbms/article/view/32

Brunelli, Sandro, Chiara Carlino, Rosella Castellano, and Alessandro Giosi. (2020). Going Concern Modifications and Related Disclosures in the Italian Stock Market: Do Regulatory Improvements Help Investors in Capturing Financial Distress? Springer US. Retrieved from https://doi.org/10.1007/s10997020-09537-7

Dai, Ratna Meisa. (2016). "Analysis of Financial Performance through Profitability Approach at Culinary Center in Cimahi City." 5(2):364-70. Retrieved from https://www.sibresearch.org/uploads/3/4/0/9/34097180/riber_xk16088_364-370_.pdf

Dirman, Angela. (2020). "Financial Distress: The Impacts of Profitability, Liquidity, Leverage, Firm Size, and Free Cash Flow." International Journal of Business, Economics and Law 22(1):17-25. Retrieved from http://ijbel.com/wpcontent/uploads/2020/08/IJBEL22_205.pdf

Disemadi, Hari Sutra, and Ali Ismail Shaleh. (2020). "Banking Credit Restructuring Policy amid COVID-19 Pandemic in Indonesia." Jurnal Inovasi Ekonomi 5(02):63-70. Retrieved from https://doi.org/10.22219/jiko.v5i3.11790

Durrah, Omar, Abdul Aziz, Abdul Rahman, Syed Ahsan Jamil, and Nour Aldeen Ghafeer. (2016). "Exploring the Relationship between Liquidity Ratios and 
Indicators of Financial Performance : An Analytical Study on Food Industrial Companies Listed in Amman Bursa." 6(2):435-41. Retrieved from https://www.researchgate.net/profile/Syed_Ahsan_Jamil/publication/297 158263_Exploring_the_Relationship_between_Liquidity_Ratios_and_Indicat ors_of_Financial_Performance_An_Analytical_Study_on_Food_Industrial_Co mpanies_Listed_in_Amman_Bursa/links/56dd532408aef38babcbf20e/Exp loring-the-Relationship-between-Liquidity-Ratios-and-Indicators-ofFinancial-Performance-An-Analytical-Study-on-Food-IndustrialCompanies-Listed-in-Amman-Bursa.pdf

Fredrick, Ikpesu. (2019). "Firm Specific Determinants of Financial Distress: Empirical Evidence from Nigeria." Journal of Accounting and Taxation 11(3):49-56. Retrieved from Https://doi.org/10.5897/JAT2019.0333

Gregova, Elena, Katarina Valaskova, Peter Adamko, Milos Tumpach, and Jaroslav Jaros. (2020). "Predicting Financial Distress of Slovak Enterprises: Comparison of Selected Traditional and Learning Algorithms Methods." Sustainability (Switzerland) 12(10). Retrieved from https://doi.org/10.3390/su12103954

Hasan, M. Iqbal. (2008). Analisis Data Penelitian Dengan Statistik. Jakarta: PT. Bumi Aksara.

Kakinuma, Yosuke. (2020). "Return Premium of Financial Distress and Negative Book Value: Emerging Market Case." Journal of Asian Finance, Economics and $\quad$ Business (8):25-31. Retrieved from https://doi.org/10.13106/jafeb.2020.vol7.no8.025

Kaplan, Greg, Giovanni L. Violante, and Greg Kaplan. (2020). "The Great Lockdown and the Big Stimulus :" Tracing the Pandemic Possibility Frontier for the U.S. Retrieved from https://www.nber.org/papers/w27794

Liang, Deron, Chih Fong Tsai, Hung Yuan (Richard) Lu, and Li Shin Chang. (2020). "Combining Corporate Governance Indicators with Stacking Ensembles for Financial Distress Prediction." Journal of Business Research 120(December 2019):137-46. Retrieved from https://doi.org/10.1016/j.jbusres.2020.07.052

Lord, Justin, Amy Landry, Grant T. Savage, and Robert Weech-Maldonado. (2020). "Predicting Nursing Home Financial Distress Using the Altman Z-Score." Inquiry (United States) 57. Retrieved from https://doi.org/10.1177/0046958020934946

Makiwan, Gischanovelia. (2018). "Analisis Rasio Leverage Untuk Memprediksi Pertumbuhan Laba Perusahaan Manufaktur Sub Sektor Makanan Dan Minuman." Bisnis 15(2):147-72. Retrieved from https://doi.org/10.26487/jbmi.v15i2.3530

Mangena, Musa, Alba Maria Priego, and Montserrat Manzaneque. (2020). "Bank Power, Block Ownership, Boards and Financial Distress Likelihood: An Investigation of Spanish Listed Firms." Journal of Corporate Finance 64(April). Retrieved from https://doi.org/10.1016/j.jcorpfin.2020.101636

Olilingo, Fahruddin Zain, and Aditya Halim Perdana Kusuma Putra. (2020). "How Indonesia Economics Works: Correlation Analysis of Macroeconomics in 2010-2019." Journal of Asian Finance, Economics and Business 7(8):117-30. Retrieved from https://doi.org/10.13106/jafeb.2020.vol7.no8.117

Olivier Coibion, Yuriy Gorodnichenko, and Michael Weber. (2019). "HOW DID U.S. CONSUMERS USE THEIR STIMULUS PAYMENTS?" Journal of Chemical 


$\begin{array}{lllll}\text { Information and } & \text { Modeling } & \text { 53(9):1689-99. } & \text { Retrieved } & \text { from } \\ \text { https://doi.org/10.3386/w27693 } & & & \end{array}$

Paul, Ananya, and Debdas Rakshit. (2020). "Earnings Management and Financial Distress : An Analysis of Indian Textile Companies." Journal of Economics and Public Policy V(3):40-53. Retrieved from https://eppjournal.nmims.edu/wp-content/uploads/2020/08/EPP-August-2020issue-40-53.pdf

Resosudarmo, Budy P., Abdurohman, Arief A. Yusuf, and Djoni Hartono. (2020). "Spatial Impacts of Fiscal Stimulus Policies during the 2009 Global Financial Crisis in Indonesia." Asia-Pacific Journal of Regional Science (0123456789). Retrieved from https://doi.org/10.1007/s41685-020-00176-2

Sari, Warsani Purnama. (2020). "The Effect of Financial Distress and Growth Opportunities on Accounting Conservatism with Litigation Risk as Moderated Variables in Manufacturing Companies Listed on BEI." Budapest International Research and Critics Institute (BIRCI-Journal) : Humanities and Social Sciences 3(1):588-97. Retrieved from https://doi.org/10.33258/birci.v3i1.812

Souri, Mohammad Ehsan, Fatemeh Sajjadian, Reza Sheikh, and Shib Sankar Sana. (2018). "Grey SERVQUAL Method to Measure Consumers' Attitudes towards Green Products - A Case Study of Iranian Consumers of LED Bulbs." Journal of Cleaner Production 177:187-96. Retrieved from https://doi.org/10.1016/j.jclepro.2017.12.105

Sudaryo, Yoyo, Wiara Sanchia Grafita Ryana Devi, Dyah Purnamasari, Astrin Kusumawardani, and Ana Hadiana. (2021). "Pengaruh Current Ratio (CR), Debt To Equity Ratio (DER) Terhadap Net Profit Margin (NPM)." EKONAM: Jurnal Ekonomi 3(1):11-22.

Sudaryo, Yoyo, Mohd Hassan, Che Haat, Jumadil Saputra, Mohd Yusoff Yusliza, Zikri Muhammad, and Abdul Talib Bon. (2021). "Factors That Affect Financial Distress: An Evidence from Jakarta Stock Exchange Listed Companies , Indonesia." (2010). Retrieved from https://d1wqtxts1xzle7.cloudfront.net/66039823/Yoyo_Sudaryo_et_al._20 20_SRN_Intellectual_Resources_-with-cover-page-

v2.pdf?Expires $=1633761489 \&$ Signature $=$ CovkhaThgIT7qRbw5uZnAFx84I 9MJEjNj0vQF986Nsokoefzb7ylQzpePQSzok2xjPIRy1eCpj1Uhrip9VdIZCVEj KDMbnDwRUzuRM67gabRCTFoaAnfqmNcZJw6lXDhoidGbabgXemRVFAE3 SY-

3VMiEMSOWN2q4B8GwpgVJNJyy32IUI2Up2uvalxwgHhmDNoIcF1Kn7i8G dj4I3lyhTtswYkEiiTRpy87dJ1RCd9cd7gcUzlyF57Au88vHzFYohgyqCWrRE arSBaUl2q3h5gFQ6JeDUQePjtkc6Xih596KYHndiCQSJhmsGk46BKQLdGoZq AWC-CS9uOM38wm9Q_\&Key-Pair-Id=APKAJLOHF5GGSLRBV4ZA

Sugiyono. (2014). Metode Penelitian Pendidikan Pendekatan Kuantitatif, Kualitatif, Dan R\&D. Bandung: Alfabeta.

Sutrisno. (2012). Manajemen Keuangan Teori, Konsep Dan Aplikasi (8th.). Yogyakarta : Ekonisia.

Wu, Liu, Zhen Shao, Changhui Yang, Tao Ding, and Wan Zhang. (2020). "The Impact of CSR and Financial Distress on Financial Performance-Evidence from Chinese Listed Companies of the Manufacturing Industry." Sustainability (Switzerland) 12(17). Retrieved from https://doi.org/10.3390/su12176799

Wufron. (2017). "Pengaruh Ukuran Perusahaan Terhadap Kinerja Keuangan Serta Implikasinya Terhadap Nilai Perusahaan Pada Perusahaan Manufaktur 
Yoyo Sudaryo, Nunung Ayu, Sofiati (Efi), Ita Kumaratih, Nandan Limakrisna, Mohd Hassan Che Haat, Zikri Muhammad, Astrin Kusumawardani, and Jumadil Saputra

Yang Terdaftar Di Bursa Efek Indonesia." Jurnal Wacana $\begin{array}{r}\text { Ekonomi } \\ \text { Retrieved }\end{array}$
$\begin{aligned} & \text { 16(3):022-033. } \\ & \text { https://journal.uniga.ac.id/index.php/JA/article/view/404 }\end{aligned}$

Yan, Dawen, Guotai Chi, and Kin Keung Lai. (2020). "Financial Distress Prediction and Feature Selection in Multiple Periods by Lassoing Unconstrained Distributed Lag Non-Linear Models." Mathematics 8(8). Retrieved from https://doi.org/10.3390/math8081275 